DOI: 10.1002/adma.((please add manuscript number))

Article type: Communication

\title{
Endocytic pH-Triggered Degradation of Nanoengineered Multilayer Capsules
}

Kang Liang, Georgina K. Such, Angus P. R. Johnston, Zhiyuan Zhu, Hirotaka Ejima, Joseph J. Richardson, Jiwei Cui, and Frank Caruso*

K. Liang, Dr. G. K. Such, Dr. A. P. R. Johnston, Dr. Z. Zhu, Dr. H. Ejima, J. J. Richardson, Dr. J. Cui, and Prof. F. Caruso

Department of Chemical and Biomolecular Engineering, The University of Melbourne, Parkville, Victoria 3010, Australia

E-mail: (fcaruso@unimelb.edu.au)

Keywords: (drug delivery, polymer capsules, layer-by-layer, nanotechnology, biomaterials)

The design of stimuli-responsive polymeric drug carriers is a burgeoning research area because such carriers can selectively degrade and release therapeutic agents inside target cells, thereby improving therapeutic outcomes. ${ }^{[1]}$ A range of stimuli-responsive mechanisms have been integrated into responsive carriers for achieving selective and site-specific degradation through both biological and non-biological triggers. ${ }^{[2]}$ Among them, carriers with biological triggers (e.g., pH, redox, and enzyme) are attracting particular interest because they can respond to naturally occurring conditions and variations within cells. Specifically, the $\mathrm{pH}$ drop experienced during endocytosis is a desirable trigger because it is universal across cell lines and extensively studied. ${ }^{[3]}$ Furthermore, polymer carriers are typically internalized via endocytic pathways, and therefore the $\mathrm{pH}$ shift between the extracellular environment $(\mathrm{pH}$ 7.4) and endosomal vesicles $(\mathrm{pH}$ 6.5-4.5) is an attractive biological trigger for degradation and drug release. ${ }^{[3]}$ To harness this trigger, several pH-degradable liposomes/polymersomes and polymer nanoparticles have been reported. ${ }^{[4]}$ However, for layer-by-layer (LbL) assembled capsules, which are an emerging class of polymer drug carriers, cellular $\mathrm{pH}$ triggered degradation has not been demonstrated. 
LbL assembly has proven to be a robust and versatile technique for synthesizing polymer capsules, largely due to the ability to fine-tune the physicochemical properties and functionality of the obtained capsules. ${ }^{[5]}$ However, the narrow $\mathrm{pH}$ shift experienced during endocytosis has made it difficult to assemble capsules with the relevant $\mathrm{pH}$ degradability. ${ }^{[6]}$ As a result, LbL capsules have been designed to be sensitive to other cellular triggers (i.e., redox reactions and enzymes) to cause capsule degradation and subsequent cargo release. Unlike $\mathrm{pH}$ reductions experienced during endocytosis, the concentrations of "redox chemicals” (e.g., glutathione) and enzymes in the endosomal compartments vary for different cells. ${ }^{[7]}$ Therefore, it is desirable to design LbL capsules that can be degraded by the wellcharacterized reduction in $\mathrm{pH}$ experienced during the endocytic process so the degradation mechanism is broadly applicable to a range of cells. Herein, we report, for the first time, the synthesis of LbL capsules that degrade solely in response to endocytic $\mathrm{pH}$ changes. We also demonstrate their use for encapsulating and delivering various small model drugs and therapeutics.

The capsules prepared are based on the charge-shifting polymer, poly(2diisopropylaminoethyl methacrylate) (PDPA). ${ }^{[8]}$ To achieve endocytic pH-induced degradation of the PDPA-based capsules, we engineered PDPA with a minor component of lauryl methacrylate (PDPA $\mathrm{C} 12_{2}$ ), and used PDPA $\mathrm{C}_{12}$ as the building block for capsule assembly. The use of the modified PDPA permits the formation of PDPA $\mathrm{C}_{12}$ multilayers through noncovalent stabilization, allowing for the assembly of highly $\mathrm{pH}$-responsive, single-component multilayer capsules. This represents a significant difference from our previous work on PDPA capsules stabilized with a disulfide-containing cross-linker, where a combination of intracellular reducing conditions and $\mathrm{pH}$ changes was required to degrade the capsules. ${ }^{[8]}$ Further, in the absence of $\mathrm{C}_{12}$ groups on PDPA, stable capsules could not be formed without chemically cross-linking the PDPA capsules. ${ }^{[8]}$ The addition of $\mathrm{C}_{12}$ groups in the PDPA is 
pporting Information, Figure S1), which expected to increase the overall hydrophobicity (Supporting Information, Figure S1), which could non-covalently stabilize the multilayers at $\mathrm{pH} 7.4$ (Scheme 1). The merging of $\mathrm{pH}$ degradable and non-covalently stabilized polymer multilayer capsules, as reported in the current study, offers a number of important advantages. Firstly, the synthesized capsules are stable at physiological $\mathrm{pH}(\mathrm{pH}$ 7.4) and respond to narrow cellular $\mathrm{pH}$ shifts and degrade rapidly under endosomal $\mathrm{pH}$. Secondly, the assembled capsules demonstrate $\mathrm{pH}$-dependent encapsulation and release of hydrophilic molecules (e.g., therapeutic agents) with a wide range of molecular weights ( 500 Da to $\sim 70 \mathrm{kDa}$ ), improving the capacity to encapsulate small (less than $10 \mathrm{kDa}$ ) molecules in polymer hydrogel capsules. ${ }^{[9]}$ Thirdly, this encapsulation strategy overcomes the limitations of conjugating small therapeutics to the carrier, which involves chemical reactions, can be time consuming, and may alter the properties of the molecules. Fourthly, the prepared capsules are stabilized via hydrophobic interactions, avoiding the use of potentially toxic substances such as $\mathrm{Cu}(\mathrm{I})$, which is involved in some chemical cross-linking processes. ${ }^{[10]}$ This non-covalent stabilization method is expected to have application in a wide range of responsive multilayer drug carriers.

PDPA $_{\mathrm{C} 12}$ was synthesized with a minor component of lauryl methacrylate and a short poly(ethylene glycol) methacrylate side group via atom transfer radical polymerization (ATRP) using an azide-containing initiator (see Supporting Information). The azide groups at the polymer end can be used for post-functionalization of the capsules via click chemistry. This could involve dyes for imaging or antibodies for targeting. ${ }^{[11]}$ NMR characterization showed that the $\mathrm{C}_{12}$ and PEG contents from the PDPA $\mathrm{C}_{\mathrm{C} 22}$ were $\sim 10 \%$ and $\sim 8 \%$, respectively (see Supporting Information). LbL assembly between $\mathrm{PDPA}_{\mathrm{C} 12}$ and PMA at $\mathrm{pH} 4$ was investigated firstly on planar gold substrates using a quartz crystal microbalance (QCM). Film assembly is likely to be a combination of hydrogen bonding between protonated carboxyl groups of PMA and the PEG moieties in the PDPA $\mathrm{C}_{\mathrm{C} 2}$, as well as electrostatic interactions 


\section{Submitted to \\ ADVANCED
MATERIALS}

between charged PMA and PDPA $\mathrm{C} 12_{2}$ tertiary amine groups (Supporting Information, Figure S2). ${ }^{[8]}$ Uniform buildup of five PDPA $_{\mathrm{C} 12} / \mathrm{PMA}$ bilayers was observed (Supporting Information, Figure S3). Using the Sauerbrey equation, the mass deposited for each PDPA $\mathrm{C}_{\mathrm{C} 2}$ and PMA layer was calculated to be 350 and $400 \mathrm{ng} \mathrm{cm}^{-2}$, respectively, which are similar to those observed for electrostatically-associated LbL films. ${ }^{[12]}$ Upon increasing the $\mathrm{pH}$ to above the pKa ( 6.4) of the tertiary amine groups in the PDPA, more than 99\% of the PMA was removed from the multilayers (Supporting Information, Figure S3).

$\mathrm{PDPA}_{\mathrm{C} 12} / \mathrm{PMA}$ multilayer growth was then investigated on $\sim 2.6 \mu \mathrm{m}$-diameter spherical silica particles using flow cytometry. A linear increase in the intensity of Alexa Flour 488-labeled PMA was observed for PDPA $\mathrm{C} 12_{2} / \mathrm{PMA}$ multilayer assembly, suggesting regular growth of the multilayers (Supporting Information, Figure S4a). Following deposition of five bilayers, the silica particles were removed, leaving hollow multilayer capsules (Figure 1). Flow cytometry confirmed removal of PMA upon raising the $\mathrm{pH}$ to 7.4 for 5 min (Supporting Information, Figure S4b). Furthermore, controlled reversible shrinking and swelling over three cycles was observed upon varying the $\mathrm{pH}$ from 7.4 to 6.0. The swollen capsules were stable for $24 \mathrm{~h}$ without shaking. Fluorescence microscopy and TEM images of these capsules prepared on silica particles showed reversible size changes from $1.2 \mu \mathrm{m}$ to $3.5 \mu \mathrm{m}$ at $\mathrm{pH} 7.4$ and 6.0, respectively (Figure 1). Compared with the covalently cross-linked PDPA capsules reported earlier, ${ }^{[8]}$ these non-covalently stabilized PDPA capsules showed more significant $\mathrm{pH}$-induced size responses (tripling size versus doubling size).

Due to the semipermeable nature of polymeric hydrogel capsules, it is often challenging to retain small water-soluble therapeutic molecules (below $10 \mathrm{kDa}){ }^{[9]}$ One of the advantages of PDPA $_{\mathrm{C} 12}$ capsules is the significant size change due to the hydrophilic to hydrophobic shift, which can be explored to achieve $\mathrm{pH}$-selective permeability of small water-soluble molecules. 


\section{Submitted to

To demonstrate the feasibility of $\mathrm{pH}$-controlled permeation of PDPA $\mathrm{C} 12_{2}$ capsules, fluorescein isothiocyanate (FITC)-labeled dextran of different molecular weights was used as a fluorescent probe (Supporting Information, Figure S5). At pH 7.4, the capsules were found to be impermeable to the FITC-dextran of different molecular weights (4-500 kDa) due to the hydrophobic nature of the capsule shell. However, at pH 6.0, the capsules swelled and became permeable to FITC-dextran of molecular weight up to $500 \mathrm{kDa}$ (Figure 2; Supporting Information, Figure S5). The pH-dependent capsule permeability to a water-soluble model drug, rhodamine 6G (R6G, 479 Da) was also investigated. (The R6G-loaded capsules were used to demonstrate intracellular cargo release-see later.) The results indicate that PDPA $\mathrm{C}_{\mathrm{C} 2}$ capsules at $\mathrm{pH} 7.4$ remained impermeable to R6G (Figure 2). These results suggest that the hydrophobic shell of PDPA $\mathrm{C} 12_{2}$ capsules at physiological $\mathrm{pH}$ prevents the trafficking of small molecules, whereas at endosomal $\mathrm{pH}$, these capsules swell, causing free diffusion of these molecules across the capsule walls.

To demonstrate the effective encapsulation and release of small hydrophilic therapeutic agents, an oligonucleotide adjuvant ${ }^{[13]}$ (FITC-labeled CpG, negative charge, $\sim 6.5 \mathrm{kDa}$ ) and a cell penetrating peptide (FITC-labeled peptide with the sequence of R4H4 positive charge, 1.7 $\mathrm{kDa}$ ) were used as model therapeutics. PDPA $\mathrm{C}_{12}$ capsules were incubated in $\mathrm{pH}$ 6.0 PBS containing the small hydrophilic molecules for one minute without shaking. This allows for diffusion of the molecules into the capsules. The swollen capsules were stable for $24 \mathrm{~h}$ without shaking. The capsules were then transferred into $\mathrm{pH} 7.4$ PBS to lock the molecules inside the hollow core of the capsules, followed by three wash cycles to remove excess molecules. At pH 7.4, successful encapsulation of both DNA and peptide was demonstrated. The average amount of DNA or peptide loaded inside each capsule was calculated to be 2.1 pg and 4.7 pg, respectively, as determined from fluorescence spectroscopy according to predetermined calibration curves (data not shown). The DNA appeared mostly on the capsule 


\section{Submitted to

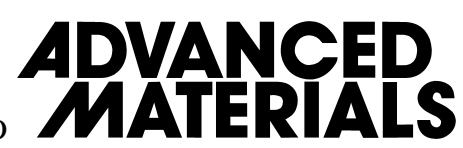

wall due to the electrostatic interaction between the negative charged DNA and slightly positively charged multilayers (Figure 3a). On the other hand, the positively charged peptides were distributed evenly in the capsules (Figure 3c). Upon reduction of $\mathrm{pH}$ to 6.0 to simulate endosomal conditions, successful release of the cargo was observed within $10 \mathrm{~s}$ due to the capsule swelling and subsequent deconstruction, as seen the fluorescence evenly distributed in the solution (Figure 3b, d).

The PDPA $\mathrm{A}_{\mathrm{C} 2}$ capsules were expected to rapidly respond the physiological $\mathrm{pH}$ changes during endocytosis, causing rapid degradation specifically in the acidic cellular compartments. To examine the pH-selective degradability of $\mathrm{PDPA}_{\mathrm{C} 12}$ capsules, they were incubated in both $\mathrm{pH}$ 7.4 and 6.0 at $37{ }^{\circ} \mathrm{C}$ (with constant shaking) to simulate the extracellular and endosomal conditions, respectively. The total number of capsules in each sample was monitored by flow cytometry over time. At $\mathrm{pH} 7.4,>90 \%$ of the capsules remained at the end of the assay (Figure 4a), and these capsules showed excellent colloidal stability for months (data not shown). In contrast, at $\mathrm{pH} 6.0$, more than $80 \%$ of the capsules were degraded within 10 min, demonstrating their rapid and $\mathrm{pH}$-selective degradation.

The cellular interactions between PDPA $\mathrm{C} 12_{2}$ capsules and JAWS II cells were studied to examine their intracellular degradation and cargo release. R6G was loaded in the capsules as a small model drug. JAWS II is an immortalized immature dendritic cell (DC) line harvested from mouse bone marrow. DCs play a critical role in activating both $\mathrm{T}$ and $\mathrm{B}$ cells during an immune response, and are widely studied as a target cell line for immunotherapy against cancers and infectious diseases. ${ }^{[14]}$ AF488-labeled PDPA ${ }_{\mathrm{C} 12}$ capsules were incubated with JAWS II cells for $2 \mathrm{~h}$ at $4{ }^{\circ} \mathrm{C}$ to associate the capsules on the cell membrane (without active uptake), and the temperature was then raised to $37^{\circ} \mathrm{C}$ prior to live cell imaging. Evidence of capsule degradation within 10 min was observed, as seen by the transformation of their shape 
from intact capsules to smaller fluorescent fragments and diffused fluorescence (Figure $4 \mathrm{~b}$ ). In contrast, the R6G signal showed diffused fluorescence in the cells, suggesting the cargo was successfully released in the cell cytosol. Furthermore, 3-(4,5-dimethylthiaol-2-yl)-2,5diphenyltetrazolium bromide (MTT) assays were performed to evaluate the cytotoxicity of PDPA $_{\mathrm{C} 12}$ capsules against HeLa cells (Supporting Information, Figure S6). The results showed negligible influence on cell viability even at high capsule dosages (capsule-to-cell ratio up to 200:1).

In conclusion, we have reported the synthesis of cross-linker free, endocytic pH-degradable multilayer capsules through non-covalent stabilization. These capsules can successfully load and release hydrophilic molecules within a wide range of molecular weights (from 0.5 to 500 $\mathrm{kDa}$ ). Further, physiological $\mathrm{pH}$ variations from extracellular to intracellular acidic compartments trigger capsule degradation and cargo release within $10 \mathrm{~min}$, highlighting the potential of these capsules as intracellular delivery vehicles.

\section{Experimental Section}

Capsule Preparation: $100 \mu \mathrm{L}$ of a $\mathrm{SiO}_{2}$ particle suspension (5 wt \%, $2.59 \mu$ m-diameter; Microparticles GmbH, Berlin, Germany) was centrifuged and washed three times in sodium acetate buffer ( $\mathrm{pH} \mathrm{4,} 50 \mathrm{mM}$ ). This procedure was used as the standard washing procedure. Assembly of the polymers was achieved by consecutive incubation of the silica templates with $200 \mu \mathrm{L}$ of PMA $\left(1 \mathrm{mg} \mathrm{mL}^{-1}\right)$ at pH 4 in Milli Q water and $200 \mu \mathrm{L}$ of PDPA $\mathrm{C}_{12}\left(1 \mathrm{mg} \mathrm{mL}^{-}\right.$ ${ }^{1}$ ) at $\mathrm{pH} 4$ in $50 \mathrm{mM}$ sodium acetate buffer with constant shaking at $23^{\circ} \mathrm{C}$. A 15 min adsorption time was allowed for all layers, and particles underwent three centrifugation/wash cycles before the addition of the following layer. This procedure was repeated until five bilayers of PDPA $\mathrm{C} 12_{2} / \mathrm{PMA}$ were adsorbed. Removal of the $\mathrm{SiO}_{2}$ particles to form hollow capsules was achieved by mixing the particle suspension with ammonium fluoride (13.3 M) 
buffered hydrofluoric acid (HF) (5 M) at a volumetric ratio of 1:1.5. [Caution! HF solution is highly toxic. Extreme care should be taken when handling HF solution and only small quantities should be prepared.] The capsules were then washed three times through centrifugation/wash cycles in $50 \mathrm{mM}$ sodium acetate buffer $(\mathrm{pH} 4)$. The removal of electrostatically bound PMA layers from the PDPA $\mathrm{C} 12_{2}$ multilayers was achieved by incubating capsules in borate buffer (50 mM, pH 7.4) followed by three centrifugation/wash cycles in PBS.

Fluorescent Labeling of Capsules: For a starting volume of $100 \mu \mathrm{L}$ of particles, $1.5 \mu \mathrm{L}$ of Alexa Fluor 488 alkyne (1 mg mL $\mathrm{m}^{-1}$ in DMSO), $50 \mu \mathrm{L}$ of sodium ascorbate $\left(4.4 \mathrm{mg} \mathrm{mL}^{-1}\right)$, and $50 \mu \mathrm{L}$ of copper sulfate $\left(1.8 \mathrm{mg} \mathrm{mL}^{-1}\right)$ were mixed with $150 \mu \mathrm{L}$ of sodium acetate buffer ( $\mathrm{pH}$ 4, $50 \mathrm{mM}$ ). This solution was added to the PDPA $\mathrm{C} 12_{2} / \mathrm{PMA}$ particles followed by constant shaking overnight. The particles were washed three times before removal of the core templates. At each pH an average of 20 capsules were sized using fluorescence microscopy.

Degradation of the PDPA $A_{C 12}$ Capsules: Fluorescently labeled PDPA $\mathrm{C} 12_{2}$ capsules were washed into PBS and counted using flow cytometry. Then, a set of samples with a total capsule population of $1 \times 10^{7}$ was suspended in PBS buffer, the $\mathrm{pH}$ of which was adjusted to 6.0 and 7.4. The samples were incubated at $37^{\circ} \mathrm{C}$ with constant shaking at $200 \mathrm{rpm}$ in a thermomixer (Eppendorf, Germany). At each measurement, approximately $5 \times 10^{4}$ capsules were assessed. The mean fluorescence intensity and the number of capsules were measured to determine the capsule population at each time point.

Live Cell Imaging: JAWS II cells were seeded in an 8-well chambered cover glass (Thermo Scientific) at $37{ }^{\circ} \mathrm{C}\left(5 \% \mathrm{CO}_{2}\right)$ overnight at a population of $4.0 \times 10^{5}$ cells per well. The cells were then incubated at $4^{\circ} \mathrm{C}$. Capsules were added at a capsule/cell ratio of 20:1 in each well. After $2 \mathrm{~h}$, the cells were washed with warm media $\left(37^{\circ} \mathrm{C}\right)$ twice to remove free-floating capsules. The cells were finally covered with $500 \mu \mathrm{L}$ of media in each well. The cover glass was then fitted to a DeltaVision (Applied Precision) microscope. Cells were kept alive in the 
incubation chamber, equipped with a $\mathrm{CO}_{2}$ inlet, at $37^{\circ} \mathrm{C}$ and mounted on the microscope stage, for imaging. Deconvolution images were taken on a series of z-sections within the top and bottom of the cells.

\section{Supporting Information}

Supporting Information is available online from the Wiley Online Library or from the author.

\section{Acknowledgements}

This work was supported by Australian Research Council under the Australian Laureate Fellowship FL120100030 (F.C.), Discovery Project DP0877360 (F.C.), Super Science Fellowship FS110200025 (J.C. and F.C.), and Australian Future Fellowship FT120100564 (G. K. S.) and FT110100265 (A. P. R. J.) schemes.

Received: ((will be filled in by the editorial staff))

Revised: ((will be filled in by the editorial staff))

Published online: ((will be filled in by the editorial staff))

[1] J. R. Heath, M. E. Davis, Annu. Rev. Med. 2008, 59, 251.

[2] a) S. De Koker, L. J. De Cock, P. Rivera-Gil, W. J. Parak, R. Auzély Velty, C. Vervaet, J. P. Remon, J. Grooten, B. G. De Geest, Adv. Drug Delivery Rev. 2011, 63, 748; b) G. B. Sukhorukov, A. Fery, M. Brumen, H. Möhwald, Phys. Chem. Chem. Phys. 2004, 6, 4078; c) S. L. Ng, G. K. Such, A. P. R. Johnston, G. Antequera-García, F. Caruso, Biomaterials 2011, 32, 6277; d) K. Liang, G. K. Such, Z. Zhu, S. J. Dodds, A. P. R. Johnston, J. Cui, H. Ejima, F. Caruso, ACS Nano 2012, 6, 10186; e) L. Shi, C. Berkland, Macromolecules 2007, 40, 4635.

[3] a) J. R. Casey, S. Grinstein, J. Orlowski, Nat. Rev. Mol. Cell Biol. 2010, 11, 50; b) I. A. Khalil, K. Kogure, H. Akita, H. Harashima, Phamacol. Rev. 2006, 58, 32.

[4] a) S. Ganta, H. Devalapally, A. Shahiwala, M. Amiji, J. Controlled Release 2008, 126, 187; b) W. Chen, F. Meng, R. Cheng, Z. Zhong, J. Controlled Release 2010, 142, 40; c) F. C. Giacomelli, P. Stepanek, C. Giacomelli, V. Schmidt, E. Jager, A. Jager, K. Ulbrich, Soft Matter 2011, 7, 9316; d) J. Du, S. P. Armes, J. Am. Chem. Soc. 2005, 127, 12800.

[5] a) M. Delcea, H. Möhwald, A. G. Skirtach, Adv. Drug Delivery Rev. 2011, 63, 730; b) A. L. Becker, A. P. R. Johnston, F. Caruso, Small 2010, 6, 1836; c) K. Ariga, J. P. Hill, Q. Ji, 


\section{Submitted to

Phys. Chem. Chem. Phys. 2007, 9, 2319; d) G. K. Such, A. P. R. Johnston, F. Caruso, Chem. Soc. Rev. 2011, 40, 19; e) K. Ariga, Q. Ji, J. P. Hill, Y. Bando, M. Aono, NPG Asia Materials 2012, 4, e17; f) T. A. Kolesnikova, A. G. Skirtach, H. Möhwald, Expert Opin. Drug Delivery 2013, 10, 47.

[6] K. Sato, K. Yoshida, S. Takahashi, J.-i. Anzai, Adv. Drug Delivery Rev. 2011, 63, 809.

[7] a) S. Bauhuber, C. Hozsa, M. Breunig, A. Göpferich, Adv. Mater. 2009, 21, 3286; b) O. W. Griffith, A. Meister, Proc. Natl. Acad. Sci. U. S. A. 1979, 76, 5606; c) Y. Yan, M. Björnmalm, F. Caruso, Chem. Mater., DOI: 10.1021/cm402126n.

[8] a) K. Liang, G. K. Such, Z. Zhu, Y. Yan, H. Lomas, F. Caruso, Adv. Mater. 2011, 23, H273; b) K. Liang, G. K. Such, Z. Zhu, S. J. Dodds, A. P. R. Johnston, J. Cui, H. Ejima, F. Caruso, ACS Nano 2012, 6, 10186.

[9] a) B. G. De Geest, N. N. Sanders, G. B. Sukhorukov, J. Demeester, S. C. De Smedt, Chem. Soc. Rev. 2007, 36, 636; b) A. G. Skirtach, A. M. Yashchenok, H. Möhwald, Chem. Commun. 2011, 47, 12736.

[10] a) J.-F. Lutz, Z. Zarafshani, Adv. Drug Delivery Rev. 2008, 60, 958; b) G. K. Such, E. Tjipto, A. Postma, A. P. R. Johnston, F. Caruso, Nano Letters 2007, 7, 1706; c) M. Motornov, Y. Roiter, I. Tokarev, S. Minko, Prog. Polym. Sci. 2010, 35, 174; d) G. K. Such, A. P. R. Johnston, K. Liang, F. Caruso, Prog. Polym. Sci. 2012, 37, 985.

[11] A. P. R. Johnston, M. M. J. Kamphuis, G. K. Such, H. H. Dam, R. A. Evans, A. M. Scott, E. C. Nice, J. K. Heath, F. Caruso, J. Am. Chem. Soc. 2010, 132, 15881.

[12] E. Tjipto, J. F. Quinn, F. Caruso, Langmuir 2005, 21, 8785.

[13] J. Cui, R. De Rose, J. P. Best, A. P. R. Johnston, S. Alcantara, K. Liang, G. K. Such, S. J. Kent, F. Caruso, Adv. Mater. 2013, 25, 3468.

[14] a) X. Jiang, C. Shen, J. Rey-Ladino, H. Yu, R. C. Brunham, Infect. Immun. 2008, 76, 2392; b) R. M. Steinman, Annu. Rev. Immunol. 1991, 9, 271. 


\section{Submitted to \\ ADVANCED}

(a)

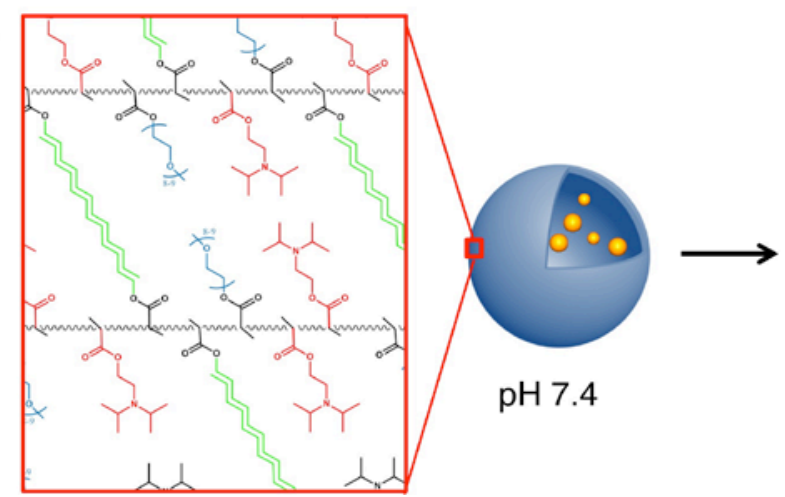

(b)

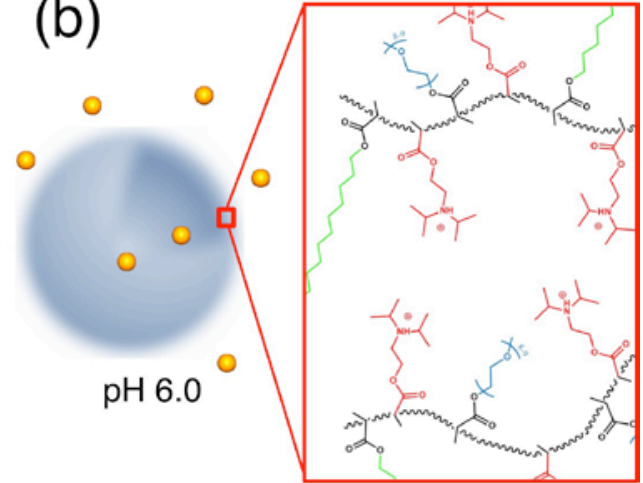

Scheme 1. a) Multilayered PDPA capsules containing hydrophobic $\mathrm{C}_{12}$ groups (green) and DPA groups (red) at $\mathrm{pH}$ 7.4. b) Reducing the $\mathrm{pH}$ to below 6.4, to mimic endosomal $\mathrm{pH}$ conditions, results in protonation of DPA, causing charge repulsion between polymer layers, leading to rapid deconstruction of the capsules and release of encapsulated therapeutics. 


\section{Submitted to

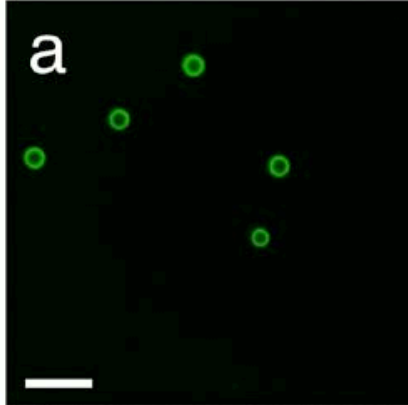

b
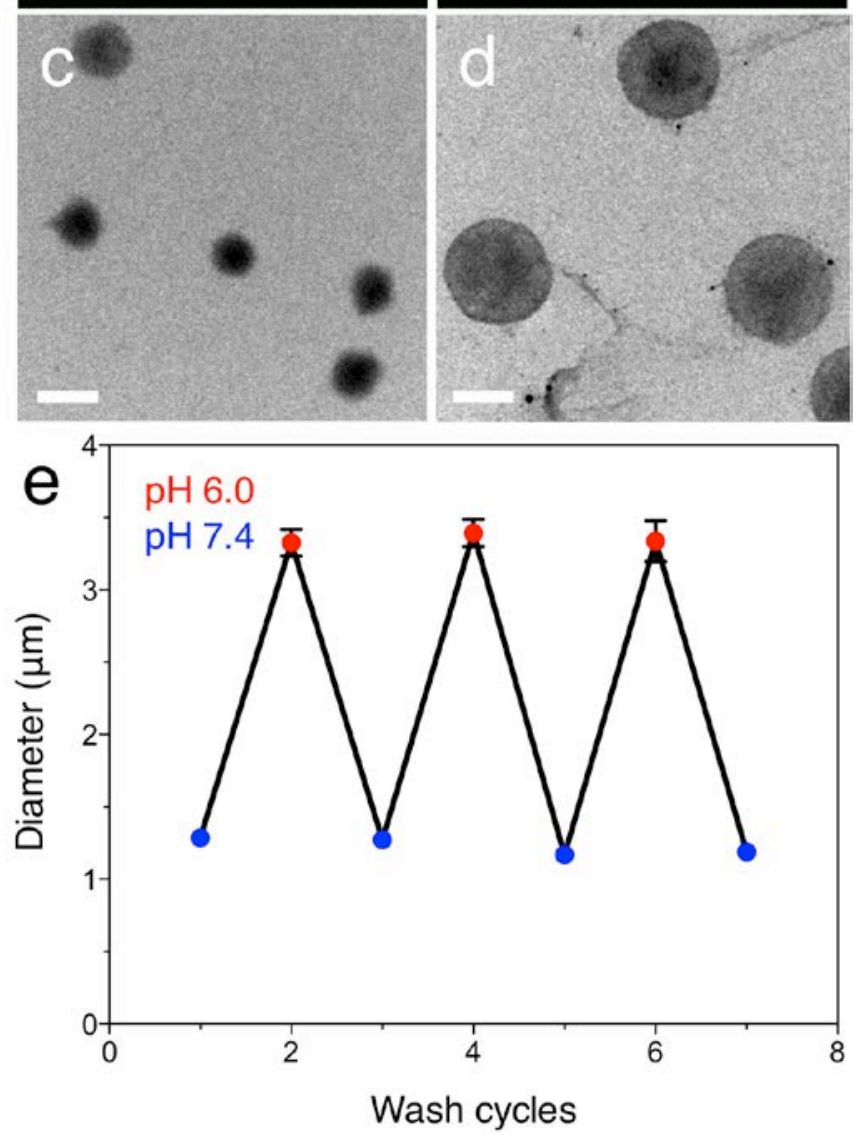

Figure 1. Non-covalently stabilized PDPA $\mathrm{C}_{\mathrm{C} 2}$ capsules obtained from $2.6 \mu \mathrm{m}$-diameter silica templates, as observed by a) and b) fluorescence microscopy (PDPA $\mathrm{C}_{12}$ capsules labeled with AF488), and c) and d) TEM at pH 7.4 (left column) and pH 6.0 (right column). Scale bars are $5 \mu \mathrm{m}$. e) Diameters of PDPA $\mathrm{C}_{12}$ capsules in response to alternate $\mathrm{pH}$ wash cycles. The diameters of 20 capsules were sized using a fluorescence microscope. 


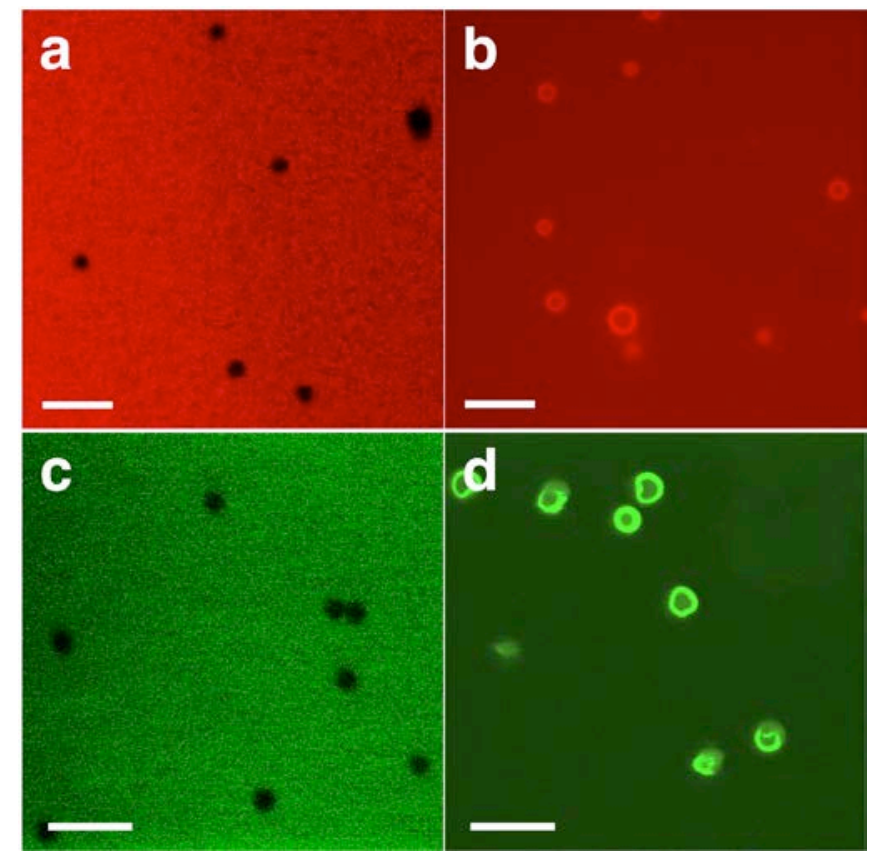

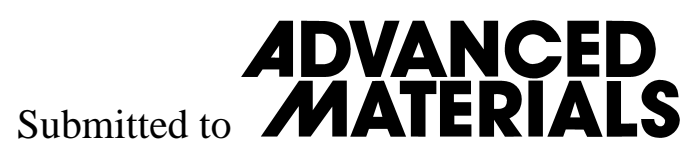

Figure 2. Confocal fluorescence microscopy images of PDPA $\mathrm{C}_{\mathrm{C} 2}$ capsules in R6G solution (in PBS) at a) $\mathrm{pH} 7.4$ and b) $\mathrm{pH}$ 6.0, and capsules in $500 \mathrm{kDa}$ FITC-dextran solution (in PBS) at c) $\mathrm{pH} 7.4$ and d) $\mathrm{pH}$ 6.0. Scale bars are $10 \mu \mathrm{m}$.

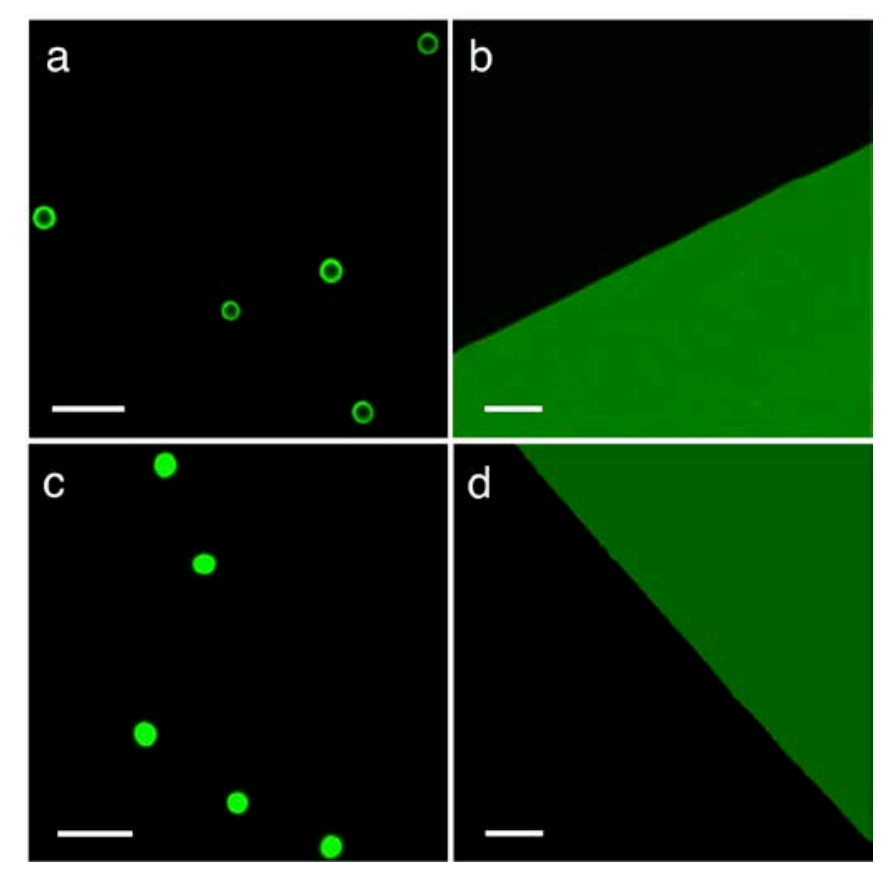

Figure 3. Confocal fluorescence microscopy images of DNA-loaded PDPA $\mathrm{C} 12_{2}$ capsules in a) $\mathrm{pH} 7.4$ and b) $\mathrm{pH}$ 6.0 PBS, and peptide-loaded PDPA $\mathrm{C} 12_{2}$ capsules in c) $\mathrm{pH} 7.4$ and d) $\mathrm{pH} 6.0$ PBS. Scale bars are $5 \mu \mathrm{m}$. 


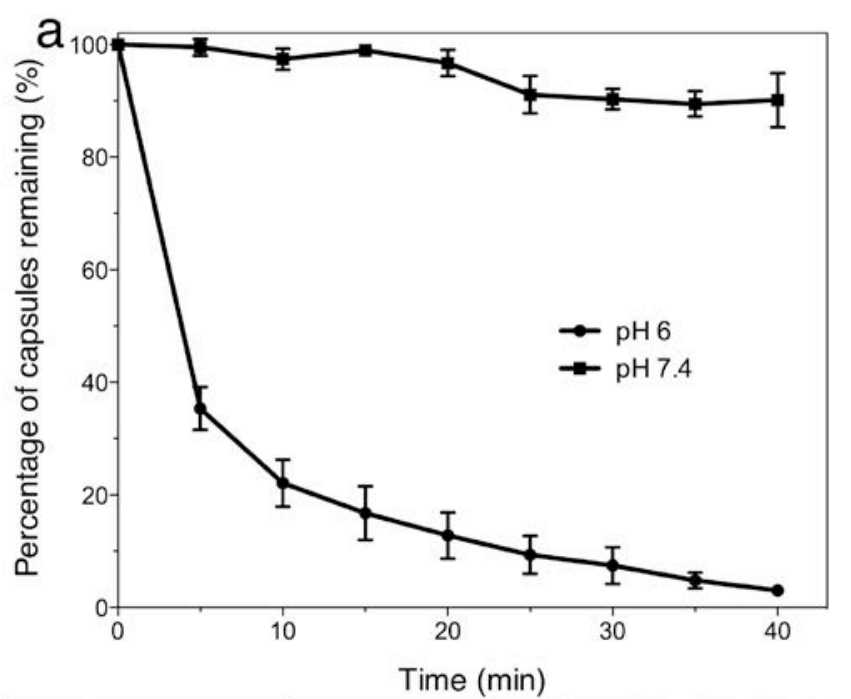

Submitted to

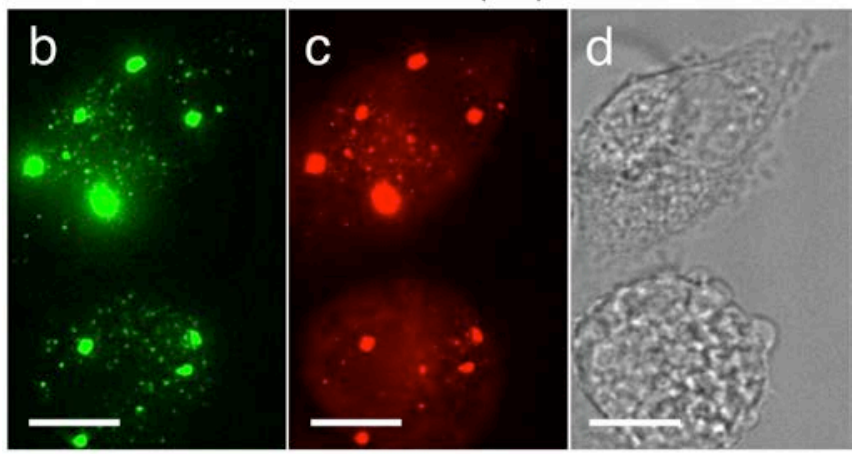

Figure 4. a) Degradation profiles of $\mathrm{PDPA}_{\mathrm{C} 12}$ capsules in $\mathrm{pH} 7.4$ (squares) and $\mathrm{pH} 6.0$ (circles) PBS, as monitored by flow cytometry. Experiments were performed in triplicate. b, c) Deconvolution optical microscopy images (maximum intensity projection) and d) DIC images of JAWS II cells incubated with R6G loaded (red) PDPA $\mathrm{C} 12_{2}$ capsules (fluorescently labeled with AF488, green) for $30 \mathrm{~min}$ at $37^{\circ} \mathrm{C}$. Capsule/cell ratio of 20:1. Scale bars are 10 $\mu \mathrm{m}$. 
The synthesis of cross-linker free layer-by-layer (LbL) capsules that solely utilize cellular $\mathrm{pH}$ variations as a trigger to specifically deconstruct and subsequently release cargo in cells is reported. These capsules demonstrate retention of water-soluble therapeutic molecules as small as $500 \mathrm{Da}$ at extracellular $\mathrm{pH}$. Triggered capsule degradation and release of cargo was observed within 10 min of cell uptake.

Keyword (drug delivery, polymer capsules, layer-by-layer, nanotechnology, biomaterials)

K. Liang, G. K. Such, A. P. R. Johnston, Z. Zhu, H. Ejima, J. J. Richardson, J. Cui, F. Caruso*

Endocytic pH-Triggered Degradation of Nanoengineered Multilayer Capsules

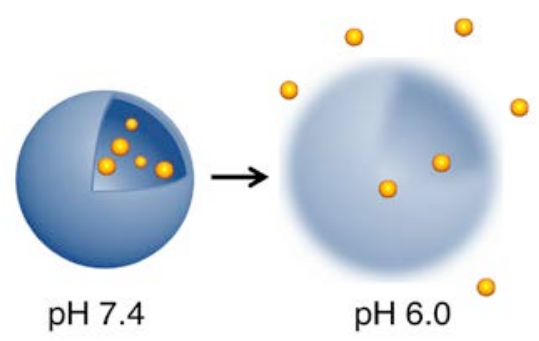




\section{University Library}

\section{- M M N E R VA A gateway to Melbourne's research publications}

Minerva Access is the Institutional Repository of The University of Melbourne

Author/s:

Liang, K;Such, GK;Johnston, APR;Zhu, Z;Ejima, H;Richardson, JJ;Cui, J;Caruso, F

Title:

Endocytic pH-Triggered Degradation of Nanoengineered Multilayer Capsules

Date:

2014-03-01

Citation:

Liang, K., Such, G. K., Johnston, A. P. R., Zhu, Z., Ejima, H., Richardson, J. J., Cui, J. \& Caruso, F. (2014). Endocytic pH-Triggered Degradation of Nanoengineered Multilayer Capsules. ADVANCED MATERIALS, 26 (12), pp.1901-1905. https://doi.org/10.1002/ adma.201305144.

Persistent Link:

http://hdl.handle.net/11343/123268 